Bangladesh J. Bot. 38(2): 127-132, 2009 (December)

\title{
MORPHOLOGY, ANATOMY AND ECOLOGY OF CRITICALLY ENDANGERED ENDEMIC CROCUS PESTALOZZAE BOISS. (IRIDACEAE) IN NORTH-WEST TURKEY
}

\author{
NeZAHAT KANDEMIR \\ Amasya University, Education Faculty, Department of Biology, Amasya-Turkey \\ Key words: Crocus pestalozzae Boiss., Endemic, Morphology, Anatomy, Ecology, Turkey
}

\begin{abstract}
Morphology, anatomy and ecology of endemic species Crocus pestalozzae Boiss. (Iridaceae), have been investigated during flowering period in early spring. The bulbous plant grows in moist heath, meadowland and rocky areas in the North-West of Turkey. Morphological properties of plant parts have been described in detail. Transverse sections of roots, stems and leaves have been illustrated and the anatomical characters of arms, keel, papillae, mesophyll and vascular bundles of leaf have been described. Population status of the plant has also been determined.
\end{abstract}

\section{Introduction}

The genus Crocus L. (Iridaceae) is distributed mainly in the Mediterranean region and comprises 80 species world-wide (Mabberley 1997). It is represented by 63 taxa (including subspecies and varieties) in Turkey of which thirty one are endemic to Turkey (Davis 1984, Davis et al. 1988, Kerndorff and Pasche 1997). Many species of the family Iridaceae are popular because of their bright, colourful, pretty flowers, and also because they grow and bloom faster than many other ornamental plants (Kandemir and Engin 2000, Baytop 1984). In addition, some Crocus species have been used for making dye, perfume and medicaments. It has been reported by Abdullaev (2003) that saffron could be effective in cancer chemoprevention in the future.

The Umraniye Crocus is one of the plants flowered in the early spring with white or lilac-blue flowers in moist heath, meadowland and rocky areas. It is distributed only in the North-West of Turkey (especially in Umraniye-Istanbul). Highest population are found in Maltepe-OmerliPendik triangular areas in Istanbul. Although it was densely distributed in the Anatolian Part of Istanbul, nowadays it is critically endangered relating to the uncontrolled, unplanned and rapid development of the city. The species has been included in the Red Data Book of Turkey in the VU (Vulnerable) category by Ekim et al. (2000).

Very recently Satıl and Selvi (2007) described the anatomy and ecology of some Crocus taxa from the west part of Turkey. In the present paper, a detailed knowledge about morphological, anatomical and ecological properties of $C$. pestalozzae have been provided. It is compared with other species of the genus Crocus.

\section{Material and Methods}

The specimens of Crocus pestalozzae Boiss. and soil samples were collected from five localities of North-west Turkey during flowering periods and these are: A2: Istanbul-Umraniye, moist heath and meadowland areas of Çekmeköy District, 80 m, 20 February 2006 - 2007, Kandemir 410. A2: İstanbul-Çataltepe moist health and meadowland areas 90 m, 23 January 20062007, Kandemir 411. A2: İstanbul-Taşdelen, moist heath, meadowland and rocky areas, 90-100 m, 17 February 2006 - 2007, Kandemir 412. A2: Kırklareli-Kıyı̈öy to Saray, meadowland areas near

E-mail: nezahat.kandemir@amasya.edu.tr 
culture areas and rocky slopes, 100-130 m, 22 February 2006 - 2007, Kandemir 413. A2: KocaeliBallıkayalar Valley, Pınarlık place, Kanyon entry, rocky and moist meadowland areas, 80 m, 28 February 2006-2007, Kandemir 414.

The taxonomic characters were studied and described according to Davis (1984). The plants flower during January to March. Fresh samples were stored in $70 \%$ alcohol. Anatomical studies were carried out using transverse sections of roots, stems and leaves of the stored and paraffininfiltrated tissues (Algan 1981).

The soil $\mathrm{pH}$, Calcium carbonate, soil texture, water holding capacity, total soluble salts have been determined according to the standard methods (Bayraklı 1987). Nitrogen, phosphorus, potassium and organic matter contents of the soils have been analyzed by micro-Kjeldahl, ammonium molybdate-tin chloride, flame photometer and the Walkley-Black methods, respectively (Kaçar 1996).

\section{Results and Discussion}

Plants are $10-25 \mathrm{~cm}$ tall. The corm is about $1.5-2.5 \times 1.2-2.5 \mathrm{~cm}$ in size, corm tunics are membranous or coriaceous, brown, separating (splitting) at the base into horizontal rings of tissues. Leaves $3-6$, synanthous, about $10-28 \mathrm{~cm} \times 1.0-1.5 \mathrm{~mm}$ in size. They are erect, green and with a distinct white median stripe. Bracteole is subequal to bract. Scape is $3-10 \mathrm{~cm}$ in size, 1flowered (Fig. 1a) during Janurary to March. Throat of perianth is yellow, sparsely pubescent. The perianth segments are $2-3.5 \times 0.5-1.2 \mathrm{~cm}$, obtuse or subacute, lilac-blue or white, yellow at inside base (Fig. 1b). Stamens 3, filaments $3-6 \mathrm{~mm}$, yellow stained blackish at base, scabridpubescent in lower half. Anthers are $6-10 \mathrm{~mm}$ long, yellow (Fig. 1d). Style is dividing into three slender orange branches and $9-16 \mathrm{~mm}$ long (Fig. le) and is usually equal to stamens. Fruit is capsule shaped, 12 - 16 $\times 7-9 \mathrm{~mm}$ (Fig. 1f). Seeds are brownish, $2-4 \mathrm{~mm}$ in diameter (Fig. 1g).

Perianth size is $2.0-3.5 \times 0.5-1.2 \mathrm{~cm}$ and most of the morphological findings are generally in agreement with those reported in the Flora of Turkey. The C. pestalozzae is a distinct taxon and need not be merged with C. biflorus aggregate. The sheathing leaves (cataphylls) are wholly green in C. pestalozzae, but scarious in C. biflorus. The small black stain at the base of each filament is an additional differentiating character of C. pestalozzae.

Epidermis of roots single layered with isodiametric cells, thin walled, $14-18 \times 16-20 \mu \mathrm{m}$ in size (Fig. 2). Cortex is $5-7$ layered consisting of ovoidal parenchyma cells, $40-60 \mu \mathrm{m}$ in diameter (Table 1). Single layered endodermis is $12-16 \mu \mathrm{m}$ diameter with thicker wall on the cortex side. Pericycle parechymatous, cells are $8-12 \mu \mathrm{m}$ diameter. Metaxylem is located on the centre while $5-6$ protoxylem are on the periphery of vascular bundles (Fig. 2). It has been observed that the roots have $5-6$ xylem strands. The thickening on the walls of the endodermal cells on the cortex side of root is clear. The same properties have been reported on the root of $C$. leichtlinii (D. Dewar) Bowles (Akan et al. 2007).

Epidermis of stem is also composed of isodiametric cells, $12-14 \times 12-16 \mu \mathrm{m}$ and without hair (Fig. 3 a, b). The cortex cells are 8 - 10 layered ovoidal in shape, 25 - $40 \mu \mathrm{m}$ diameter (Table 1). Vascular bundles 8-10 in the periphery and 4 in the centre.

Leaves consist of two long lateral arms and a rectangular keel in the middle (Fig. 4a). The arms are recurved towards the keel. Micropapillae are conspicuous on the cuticle (Fig. 4b). Both adaxial and abaxial epidermis cells are rectangular. Anticinal walls of epidermis cells in stomatal region are slightly sinuous. Stomata are anomocytic (Fig. 5b). The stomata are present in the abaxial epidermis and on the groove parts. Mesophyll consists of palisade and spongy parenchyma (Fig. 4b). The central part of the keel consists of large thin walled parenchyma cells, called lacuna. Vascular bundles are located in a row in the abaxial surface of the leaf and extend along the arms. 


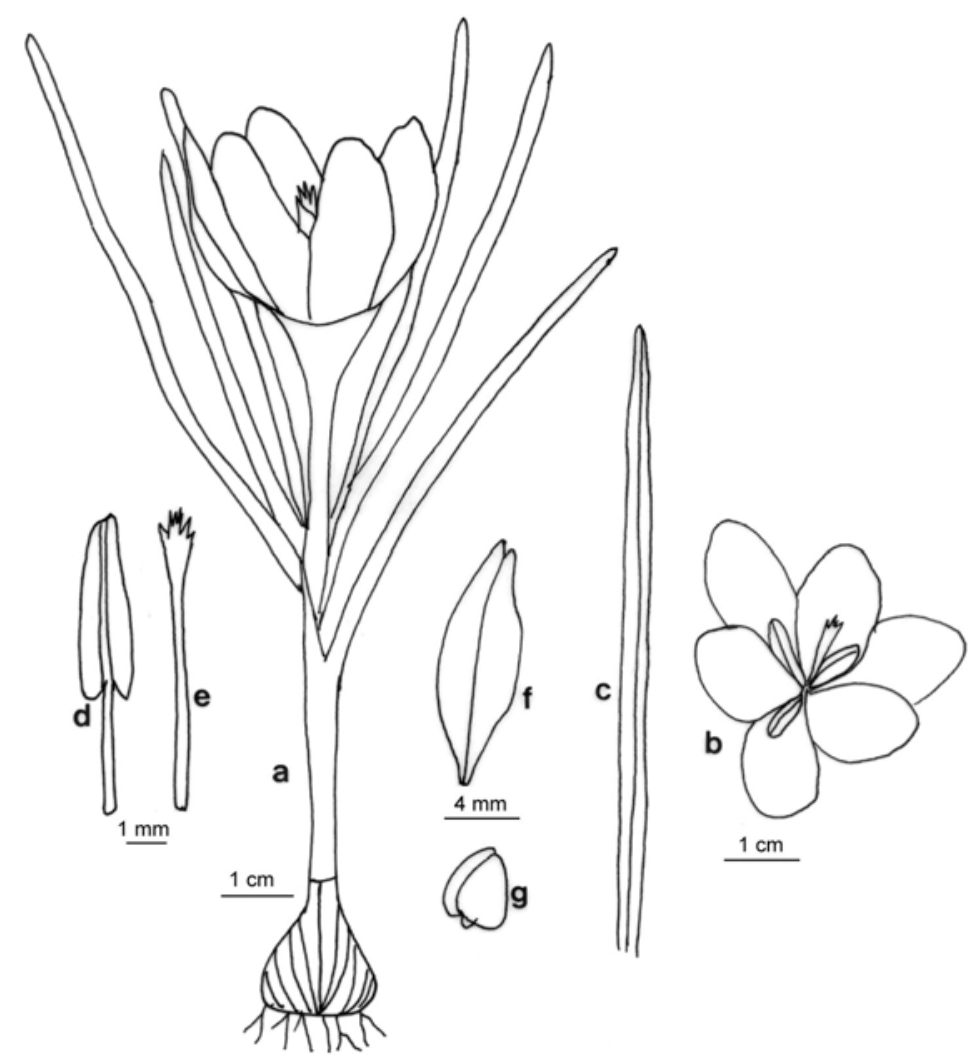

Fig. 1. General appearance and various parts of flowers of $C$. pestalozzae. a. plant, b. flower, c. leaf, d. stamen, e. style, f. fruit, g. seed.

Table 1. Dimensions of various tissues in transverse section of $C$. pestalozzae.

\begin{tabular}{llccccc}
\hline & & \multicolumn{2}{c}{ Width } & & \multicolumn{2}{c}{ Length } \\
\cline { 3 - 4 } \cline { 6 - 7 } \cline { 5 - 7 } Root & Epidermis cell & 16 & 20 & & 14 & 18 \\
& Parenchyma cell & 40 & 50 & & - & - \\
& Endodermis cell & 12 & 16 & & 4 & 7 \\
& Pericyle cell & 8 & 12 & & 5 & 7 \\
& Tracheary element & 14 & 20 & & - & - \\
\hline Stem & Epidermis cell & 12 & 16 & & 12 & 14 \\
& Parenchyma cell & 25 & 40 & & - & - \\
& Tracheary element & 16 & 20 & & - & - \\
& Phloem element & 8 & 10 & & - & - \\
& Pith parenchyma & 20 & 30 & & - & - \\
\hline Leaf & Cuticle & 8 & 12 & & - & - \\
& Upper epidermis cell & 20 & 25 & & 22 & 25 \\
& Pailsade parenchyma cell & 20 & 25 & & 45 & 50 \\
& Spongy parenchyma cell & 25 & 30 & & - & - \\
& Lower epidermis cell & 20 & 25 & & 20 & 25 \\
\hline
\end{tabular}



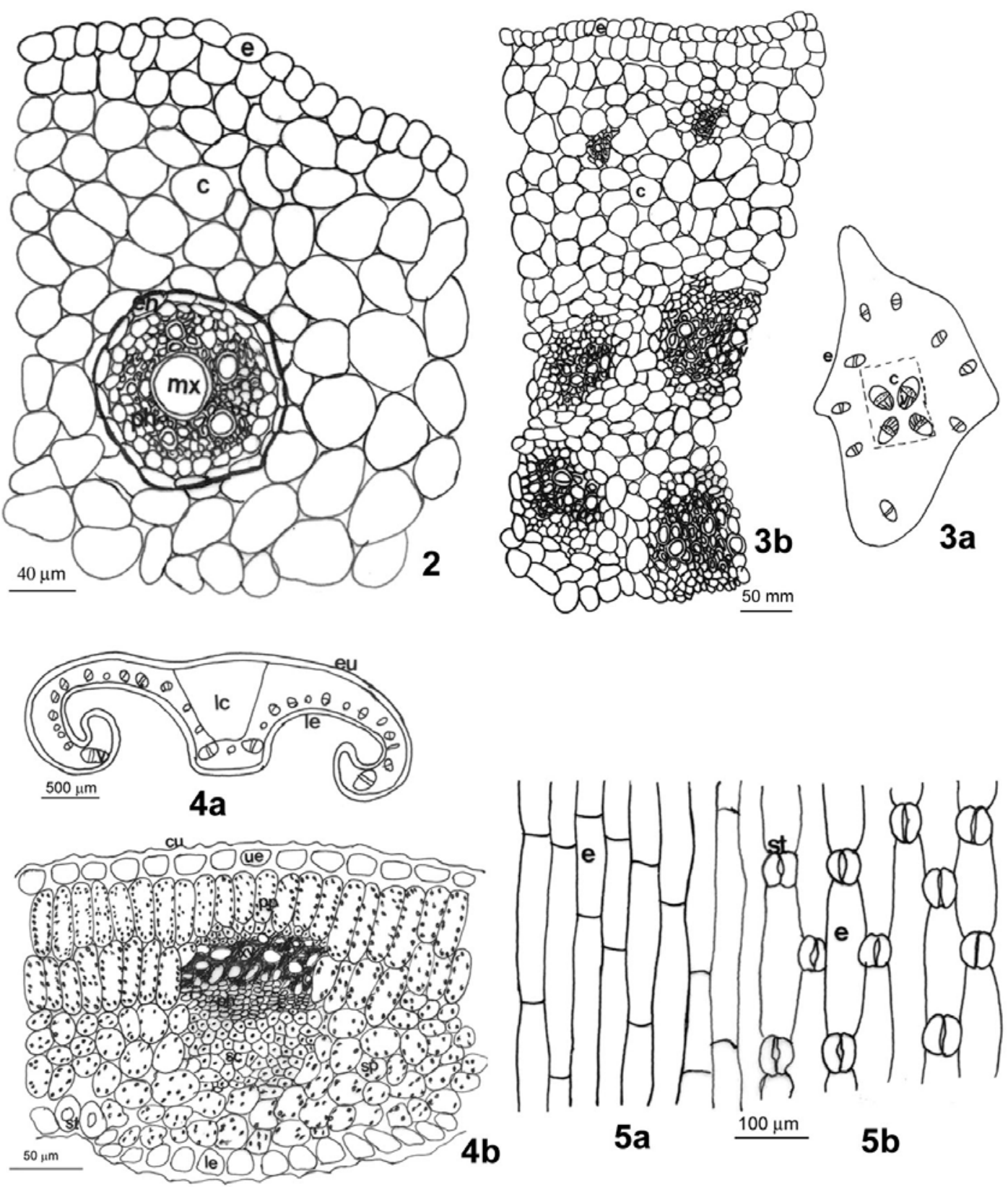

Figs 2-5. Anatomy of C. pestalozzae. 2. Cross section of a root. 3a. General appearance of a part of t.s. of a stem, b. A part of the cross section of a stem. 4a. General appearance of cross section of a leaf. b. Cross section of a portion of the leaf. 5a. Upper epidermis in surface view, b. Lower epidermis of the leaf in surface view. $(\mathrm{c}=$ cortex, $\mathrm{cu}=$ cuticle, $\mathrm{e}=$ epidermis, $\mathrm{en}=$ endodermis, $\mathrm{lc}=$ lacuna, le $=$ lower epidermis, $\mathrm{mx}=$ metaxylem, $\mathrm{ph}=$ phloem, $\mathrm{pp}=$ palisade parenchyma, $\mathrm{sc}=$ schlerenchyma, $\mathrm{sp}=$ spongy parenchyma, $\mathrm{st}=$ stomata, $\mathrm{ue}=$ upper epidermis, $\mathrm{v}=$ vascular bundle, $\mathrm{xy}=\mathrm{xylem})$.

There are four large vascular bundles two at the corners of the keel and the other two are at the end of arms. Vascular bundles are collateral type with sclerenchyma cells at the poles of longer bundles (Fig. 4b). 
Rudall and Mathew (1990) pointed out that the leaves of most species of Crocus have a distinctive cross sectional outline with a central square or rectangular "keel" and two lateral recurved "arms", which may be taxonomically significant. These properties found in $C$. pestalozzae have been observed in the leaves of C. fleischeri Gay (Erol and Küçüker 2007), C. gargaricus subsp. gargaricus, C. oliveri subsp. istanbulensis, C. pulchellus Herbert, C. flavus subsp. dissectus (Satıl and Selvi 2007), C. leichtlinii (Akan et al 2007), C. pallasii subsp. turcicus Mathew (Akan and Eker 2004) and C. ancyrensis (Herbert) Maw (Özkan et al. 1999). The leaves of the present species have a white stripe running axillary along the centre of the leaf. This is a common character in Crocus genus (Rudall and Mathew 1990, Erol and Küçüker 2007). The presence of micropapillae are important taxonomical structure of Crocus leaf anatomy and are conspicuous on the cuticle in C. pestalozzae. The anticlinal walls of epidermis cell are sinuous, the feature is also observed C. candidus (Erol and Küçüker 2007), C. oliveri subsp. istanbulensis, C. biblorus subsp. nubigena, C. pulchellus, C. chrysanthus Herbert (Sat1l and Selvi 2007) and C. leichtlinii (Akan et al. 2007).

The leaves look like bifacial with two types of parenchyma but it is homologous to unifacial leaves (Rudall 1990, Rudall and Mathew 1990). Results of this study show that there are $1-2$ layered palisade parenchyma and 3-4 layered spongy parenchyma in mesophyll of $C$. pestalozzae. These features have been observed in C. gargaricus subsp. gargaricus, C. biflorus subsp. nubigena (Herbert) Mathew, C. flavus subsp. dissectus Baytop and Mathew, C. candidus E.D. Clarke, C. pallasii subsp. pallasii and C. pulchellus (Satıl and Selvi 2007), whereas it has not been observed in the leaves of C. leichtlinii (Akan et al. 2007), C. oliveri subsp. istanbulensis Mathew, C. cancellatus subsp. mazziaricus (Herbert) Mathew (Satıl and Selvi 2007). Presence of sclerenchyma cells observed in C. pestalozzae has also been observed for C. gargaricus subsp. gargaricus, C. chrysanthus, C. biblorus subsp. nubigena, C. oliveri subsp. istanbulensis, C. pulchellus (Satıl and Selvi 2007), C. leichtlinii (Akan et al. 2007), C. fleischeri, C. wattiorum Mathew (Erol and Küçüker 2007) and C. ancyrensis (Özkan et al. 1999).

Physical and chemical properties of soils where C. pestalozzae is distributed are shown in Table 2. It is revealed that the plant grows better in soils with no salinity, medium calcareous, neutral to slightly acidic $\mathrm{pH}$ and clayey-loamy soils. The species generally prefers to grow in soils with rich organic matter, nitrogen, phosphorus and potassium. It has been observed that Iris taochia Woronow ex Grossh. (Kandemir 2006), Iris histroides Foster (Kandemir and Engin 2000), Iris pseudacorus L. (Engin et al. 1998), C. pulchellus, C. oliveri subsp. istanbulensis, C. biflorus subsp. nubigena and C. pallasii subsp. pallasii (Satıl and Selvi 2007) also prefer to grow in the same type of soils.

Table 2. Chemical properties of the Argillaceous loamy soils sampled from growing sites of $C$. pestalozzae.

\begin{tabular}{lccccccc}
\hline Locality & $\mathrm{pH}$ & $\begin{array}{c}\text { Total soluble } \\
\text { salts }(\%)\end{array}$ & $\begin{array}{c}\mathrm{CaCO}_{3} \\
(\%)\end{array}$ & $\begin{array}{c}\text { Organic } \\
\text { matter (\%) }\end{array}$ & $\mathrm{N}(\%)$ & $\begin{array}{c}\mathrm{P} \\
(\%)\end{array}$ & $\begin{array}{c}\mathrm{K} \\
(\%)\end{array}$ \\
\hline İstanbul-Ümraniye-Çekmeköy & 6.28 & 0.097 & 3.6 & 5.8 & 87.1 & 42.3 & 96.2 \\
İstanbul-Çataltepe & 6.55 & 0.061 & 2.9 & 4.7 & 82.0 & 26.5 & 57.8 \\
İstanbul-Taşdelen & 6.90 & 0.108 & 3.4 & 3.0 & 69.6 & 30.6 & 35.1 \\
Kırklareli-Kiyıköy-Saray & 7.20 & 0.070 & 2.5 & 3.9 & 40.7 & 25.7 & 72.5 \\
Kocaeli-Ballikayalar-Valley & 7.32 & 0.088 & 4.2 & 4.6 & 53.8 & 17.4 & 68.4 \\
Mean & 6.85 & 0.085 & 3.32 & 4.40 & 66.6 & 28.5 & 66.0 \\
Standard deviation & 1.75 & 1.69 & 1.78 & 2.12 & 2.30 & 2.90 & 1.99 \\
\hline
\end{tabular}

When the population density of C. pestatozzae in 2007 and 2008 was compared, it was observed that the number is decreasing because of the rapid development of the city and applying 
agro-chemicals in the culture areas (Table 3). Therefore, Crocus pestalozzae has been proposed to include in the CR (Critically endangered) rather than VU (vulnerable) category.

Table 3. The population density of $C$. pestalozzae for two years in localities from where samples were collected.

\begin{tabular}{lcc}
\hline \multirow{2}{*}{ Localities } & \multicolumn{2}{c}{ Number of plants $/ 100 \mathrm{~m}^{2}$} \\
\cline { 2 - 3 } & 2007 & 2008 \\
\hline İstanbul-Çekmeköy & 13 & 0 \\
İstanbul-Çataltepe & 8 & 4 \\
İstanbul-Taşdelen & 7 & 0 \\
Kırklareli-Kıyıöy-Saray & 10 & 5 \\
Kocaeli- Ballıkayalar Valley & 9 & 3 \\
\hline
\end{tabular}

\section{References}

Abdullaev F.L. 2003. Crocus sativus against cancer. Archives Med. Res. 34: 354

Akan H. and I. Eker. 2004. Some morphological and anatomical investigations on Autumn species of Crocus L. occurring in Şanlıurfa. Turk. J. Bot. 28: 185-191.

Akan H., I. Eker and F. Sat1l. 2007. The morphological and anatomical properties of endemic Crocus leichtlinii (D. Dewar) Bowles (Iridaceae) in Turkey. Pak. J. Bot. 39(3): 711-718.

Algan G. 1981. The microtechnic for plant tissues. Firat Üniversity, Arts and Science Faculty. Bot-No. 1. $93 \mathrm{pp}$.

Bayraklı F. 1987. Soil and plant analysis. Ondokuz May1s Univ., Agriculture Faculty. Number 17 Samsun.

Baytop T. 1984. The treatment with plants in Turkey (past and today). İstanbul Number: 40. $321 \mathrm{pp}$.

Davis P.H. (Ed.) 1984. Flora of Turkey and the East Aegean Islands. Vol. 8: 420-421. Edinburg Univ. Press, Edinburg.

Davis P.H, R.R. Mill and K. Tan. (Eds) 1988. Flora of Turkey and the East Aegean Islands (supplement I). 10. Edinburgh Univ. Press, Edinburgh. 278 pp.

Ekim T., M. Koyuncu, M. Vural, H. Duman, Z. Aytaç and N. Adıgüzel. 2000. Red data of turkish plants. The council of Protecting the Turk1sh Nature Press 18, Ankara. 96 pp.

Engin A., N. Kandemir, G. Şenel and M. Özkan. 1998. An autecological study on Iris pseudocorus L. (Iridaceae). Turk. J. Bot. 22: 335-340.

Erol O. and O. Küçüker. 2007. Leaf anatomy of some endemic Crocus L. (Iridaceae) taxa from the West Anatolia. Intl. J. Bot. 3(3): 290-295.

Kaçar B. 1996. Chemical analysis of plant and soil. 3. Soil analysis. pp. 91-170 Ankara Univ., Foundation of Education, Research and Development Publication 3, Ankara.

Kandemir N. 2006. An investigation on the autecology of Iris taochia Woronow Ex Grossh. (Iridaceae) Distributed in the North East Anatolia region. Pak. J. Biol. Sci. 9(15): 2753-2760.

Kandemir N. and A. Engin. 2000. An autecological study on Iris histrioides Foster (Iridaceae) distributed in the central Black Sea region. Turk. J. Bot. 24: 347-354.

Kerndorff H. and E. Pasche. 1997. Two remarkable taxa of the Crocus biflorus complex (Iridaceae) from northeastern Turkey. Linz. Biol. Beitr. 29(1): 591-600.

Mabberley D.J. 1997. The Plant Book. Cambridge Univ. Press, Cambridge. 558 pp.

Ozkan M., N. Kandemir and G. Şenel. 1999. A morphological study on some endemic species belonging to Iris L. and Crocus L. Ondokuz Mayıs Univ. Arts and Science Faculty J. 9-10(1): 145-170.

Rudall P. 1990. Comparative leaf morphogenesis in Iridaceae. Bot. Jahrb Syst. 112: 241-260.

Rudall P. and B. Mathew. 1990. Leaf anatomy in Crocus (Iridaceae). Kew Bull. 45: 535-544.

Sat1l S. and S. Selvi. 2007. An anatomical and ecological study of some Crocus L. taxa (Iridaceae) from the west part of Turkey. Acra Bot. Croat. 66(1): 25-33. 